\title{
Service Failures and Consumer Responses: Exploring the Antecedents of Consumer Dissatisfaction and Propensity to Complain
}

\author{
Qaiser Rashid Janjua ${ }^{1}$
}

\begin{abstract}
This qualitative research synthesizes the literature of service failure and consumer complaining behavior and presents a holistic template of service failure and consumer responses. In reviewing the literature, seven propositions are made which include consumer personal factors, causal attributions, situational and organizational factors, service failure recovery perceptions, past relationship, and switching costs that influence the sequential relationship between service failure, consumer dissatisfaction and propensity to complain respectively. A qualitative methodology is employed to ratify the propositions using faceto face structured interviews from thirty individuals having different backgrounds. It was found that the type and intensity of service failure, social stratum, state and type of consumers' emotions, beliefs, personality, attributions, perceptions of the organizational responsiveness, perceived service failure recovery mechanisms, past relationship with the brand/organization and switching costs affect consumer dissatisfaction and propensity to complain. Additional insights are also presented. Overall, this study comprehensively covers the serial responses to service failure, the underlying role of internal and external factors and integrates episodic processes of service failure and consumer complaint behavior in one model.
\end{abstract}

Keywords: consumer complaint behavior, service failure, causal attributions, service recovery perceptions, justice theory, past relationship, switching costs, dissatisfaction, propensity to complain.

\section{Introduction}

The main purpose of marketing is to achieve consumer satisfaction, enhance consumer loyalty and achieve sustained profitability. In face of cutthroat competition, more and more emphasis is being placed on consumer satisfaction and retaining

1 Assistant Professor, Air University School of Management-AUSOM and is a PhD candidate at Bahria University Islamabad Campus.. Email: qrj786@gmail.com

\begin{tabular}{lll} 
ARTICLE HISTORY & \\
\hline 14 Jun, 2017 Submission Received & 7 Sep, 2017 & First Review \\
\hline 23 Sep, 2017 Revised Version Received & 6 Oct, 2017 & Second Review \\
\hline 9 Oct, 2017 Revised Version Received & 5 Nov, 2017 & Accepted
\end{tabular}


consumers has become a primary concern for the organizations. Since services are heterogeneous, intangible, perishable, and simultaneously produced and consumed, therefore zero defects service is impossible (Berry, 1980; Fisk, Brown, \& Bitner, 1993; Choi \& Mattila, 2008; Chang \& Chang 2010; Gelbrich \& Roschk, 2011; Nikbin, Hyun, Baharun, \& Tabavar, 2015). Service industries such as healthcare, tourism, education and alike are purely 'people based' which makes them relatively more prone to service failures resulting in increased consumer dissatisfaction and intentions to complain (Swanson \& Hsu, 2011). Service failure has several antecedents on which the said service can fail, and it is paramount for the marketers to diagnose the cause of service failure for a successful prognosis of offering appropriate remedies. When dissatisfaction with the service encounter occurs, consumers are likely to complain, leave, switch, and/or engage in negative word of mouth and other damaging activities towards the organization, thus negatively impacting overall profitability, consumer commitment and loyalty (Bitner, Brown, \& Meuter, 2000; Lee \& Park, 2010; Chang \& Huang, 2013; Wen \& Chi 2013).

TARP (1979) study found that problematic experiences reduce consumer loyalty across all industries by fifteen to thirty percent. On average, consumer loyalty is likely to drop by about twenty five percent if the consumer has encountered a problem. Consequently, out of every five consumers who experience a problem, one will leave or purchase services/products from another organization/brand in the future. Dissatisfying service encounters influence organization's profitability as well. Specifically, for a service firm, a one percent decrease in consumer satisfaction corresponds to a five percent decrease in return on equity (Hart, 1988). Reichheld's (1993) data indicated that MBNA credit card company increased its profits by sixty percent in five years by increasing consumer retention by five percent. It has been projected that it costs five times more to recruit a new consumer than to retain an existing one (Reichheld \& Sasser, 1990). This negative effect on consumer loyalty was also ratified by Ding, Ho, and Li (2015) and Al-Refaie, Bata, Eteiwi, and Jalham, (2014). Further, research into complaint behavior reveals that a fraction of dissatisfied consumers complain (Dube \& Maute, 1996). The "silent dissatisfieds" simply leave, and more than fifty percent of consumers who do complain feel worse about the company after lodging their complaint (Hart, Heskett, \& Sasser, 1990).

TARP (1986) also found that, on average, across all industries, fifty percent of all consumers with problems never complain. They often take their business elsewhere. The results also show that among the consumers who register a complaint, thirty percent will not buy again. They showed sales lost over a five-year period from consumers who encounter a problem and do not buy again. The study found that the largest number of consumers is lost from those who never contact the organization 
and along with complainants who do complain but will not purchase again, the total loss becomes more than one million units per year. Multiplying this figure to a small dollar value means a huge loss in terms of lost profits.

Consequently, if service failures are impossible to avoid and their impact is enormous on overall image of the brand and profitability of the organization then it becomes increasingly important for firms to understand and manage such occurrences and minimize their adverse effects. However, in order to do so, it is essential to understand the phenomena of service failure by researching existing literature. Specifically, the purpose of this paper is to explore the antecedents of consumer complaining behavior that leads to the responses post dissatisfaction and their decision to voice and/or not voice their complaint, and the factors that affect these processes and outcomes.

\section{Literature Review}

Service failure leads to a number of consumer responses. Hirschman (1970) for the first time segmented consumer responses into behavioral and non-behavioral expression of dissatisfaction. According to him three options face a dissatisfied consumer; exit, voice and loyalty. Almost all subsequent models followed the same concept of distinguishing behavioral and non-behavioral consumer responses towards service failure. Day and Landon (1976) followed the same theory and proposed a two-level hierarchical classification scheme. The first level distinguishes between behavioral and non-behavioral responses where consumers after encountering a service failure decide if they take action or no action against the organization. In the latter case, consumer refrain from future interaction with the organization and chances are that they switch to other brands quietly. On the other hand, if they decide to take action then they decide about if they would take action in public or private. Private actions include boycotting the seller and/or engaging in negative word-of-mouth by telling family and friends to refrain from buying from a particular organization. Public actions include approaching the management for compensation, resorting to the court, getting assistance from consumer protection agencies, asking politicians for intervening and/or arranging public rallies and destruction of organization assets in extreme cases. In order to improve Day and Landon's work, Day (1984) conducted further research and reclassified the previous framework. Accordingly, consumers take action or no action to achieve specific goals i.e. redress seeking (complaining to organization or take legal action in order to attain compensation), complaining for reasons other than seeking remedies (to persuade others through negative word-ofmouth) and personal boycotting. Richins (1983) also explained three dimensions of complaining and added a fourth possibility of taking no action at all (the consumer 
keeps the dissatisfying experience with her/himself and tries to forget it).

Singh (1988) suggested almost similar framework by adding that the responses are directed towards three different types of 'objects'. Voice is targeted towards objects that are directly involved in the dissatisfying experience (organization, dealers, and retailers). Similarly, private responses are directed towards 'indirect' players involved (colleagues, friends, family etc.). Finally, third party responses are aimed at formal external parties (consumer protection agencies, courts). Later Singh (1990) proposed a model that predicts and explains variation in voice, exit, and negative word-of-mouth behaviors. He derived four groups of individuals based on their similar style of engaging in the complaint process. These groups are named as Passives, Voicers, Irates, and Activists. Voicers actively engage in complain process and show less interest in seeking support from third parties and avoid negative word-of-mouth. Irates are relatively moderate in complaining directly to the organization and are less likely to resort to third party. Activists exhibit above average response. Passives do not complain to anyone including friends/family, the service provider or a third party.

Later, Keaveney (1995) categorized responses as reluctant responses, failures to respond, and negative responses. In the same study, it was found that more than seventy percent of respondents reported switching due to a service provider's unethical behavior, including dishonesty, intimidating conduct, dangerous practices, and conflict of interest. Similarly, Liu and McClure (2001) categorized responses by using the keywords of "speak," "convince," "avoided" and "buy from another firm" as private responses. Unvoiced complaints are those where consumers after a dissatisfying experience do not complain and quietly exit and/or switch to other brands (Huang,Tsang \& Chou, 2011). Malhotra, Oly-Ndubisi, \& Agarwal (2008), and Kitapci and Dortyol (2009) divided complaints into 'private' and 'defection' categories where Word-ofMouth (WOM) was found as one of the most destructive strategies used by consumers to reduce their post purchase dissonance ( $\mathrm{Ng}$, David \& Dagger, 2011; McQuilken and Robertson, 2011). Overall, consumer complaint behavior is conceptualized as "a set of multiple (behavioral and non-behavioral) responses, some or all of which are triggered by perceived dissatisfaction with a purchase episode" (Singh, 1988, p.84).

\subsection{Typology of service failures}

Different industries face different types of service failures. However, their classification is a first step in understanding the consumer psychology. One of the most popular techniques of identifying and classifying service failures has been the Critical Incident Technique (CIT) used by Bitner et al. (1990) in services marketing literature. The CIT consists of a set of specifically defined procedures for collecting observations of human behavior and classifying them in order to make them useful in addressing 
practical problems. This technique has been widely adopted by other researchers such as Kelly, Hoffman and Davis (1993), Hoffman, Kelly, \& Rotalsky (1995). Hoffman et al. (1995), following Bitner et al. (1990) technique in categorizing service failures classified consumer responses into service system delivery failures, failure to respond to consumer needs and requests, and unprompted and unsolicited employee actions. Smith et al. (1999) in a comprehensive literature review proposed two types of service failure: outcome- and process-related failure. Miller, Craighead, and Karwan (2000) further distinguished two forms of service recovery efforts: psychological and tangible. The type of service failure is a direct precursor of the intensity of dissatisfaction and intentions to complain. Intensity is the magnitude of the loss that the consumer has faced due to the service failure (Hess, 2008). The magnitude of the service failure directly affects the consumer perceptions and the expectations about the product and if the severity of the failure is high then the consumers' tendency to complain and in spreading negative word of mouth is also high (Richins, 1987; Harris, Grewal, Mohr, $\&$ Bernhardt, 2006). Kim, Wang and Mattila (2010) employed cost-benefit theory and suggested that before making a complaint, dissatisfied consumers examine a tradeoff. If the costs and time spent on a complaint are perceived as exceeding the benefits as a result of a complaint, consumers will tend to remain silent and take no action.

Consumers are not likely to complain about low-cost, low-involvement purchases and vice versa. Also they are more prone to complain if the service failure is serious, the service itself is complicated and expensive (Landon, 1976; Richins, 1983). If the loss is not severe then consumer will be less involved in the service recovery process. When consumers face high severity service failure then they expect more atonement (Roehm \& Brady, 2007). Therefore it can be proposed that:

P1: The type and intensity of the service failure will affect the level of consumer dissatisfaction and determine the consumer propensity to complain.

\subsection{Forces behind consumer responses towards service failures}

Consumer responses towards service failures are dependent on certain psychological, behavioral, and organizational factors. Therefore, it is important to understand these forces in anticipating consumer responses.

Consumer personal factors. The literature reveals that consumer complaining behavior is dependent on their social stratum. People who are rich, more educated and are well-connected (socially active) are more courageous and motivated in voicing their complaints. On the other hand, consumers who belong to lower social stratum are less likely to voice their complaints because they feel psychologically 'weaker' in complaining to the organizations (Warland, Robert, \& Jane, 1975; Zaltman, Srivas- 
tava \& Deshpande, 1978; Kraft, 1977; Warland, Robert \& Dan, 1984; Moyer, 1984; Tronvoll, 2007; Christiaans \& Kim, 2009; Ors, Yilmaz \& Sen, 2015).

Consumer beliefs and attitudes have also been found to be linked to their propensity to complain. Consumers who believe that their efforts for complaining will make a difference are most likely to complain (Day \& Ash, 1979; Christiaans \& Kim, 2009, Tornvoll, 2007; Garin-Munoz, Perez-Amaral, Gijon \& Lopez, 2016). In addition, people who believe that the marketing practices of a certain organization or a group of organizations are deceptive, then they are most likely to complain (Zaltman et.al., 1978; Garin-Munoz et al., 2016). Some of the authors have also pointed out that when consumers feel that the problem occurred owing to the organization's part then there is a greater propensity to complain (Richins, 1983).

There is not much research conducted about how the personality traits affect consumer complaining behavior however, in general it has been suggested that individual nature leads to the type of complaining or no complaining. Aggressive and outspoken people are more likely to voice their complaints as compared to quiet and timid people (Fornell \& Westbrook, 1979). Some of the authors have explained a narrow approach of personality towards complaining. Wiggins and Jerry (1996) have described personality as a composition of five factors: neuroticism, extroversion, openness, agreeableness and conscientiousness. Two dimensions, neuroticism and extroversion have been found to be important personality factors. Neuroticism is related to negative emotions such as distress and anxiety and extroversion is related to more positive disposition. Berry, Tanford and Montgomery (2014) found the same analogy of personality traits affecting the consumer complaining behavior. Ekinci, Calderon and Siala (2016) posited that people with personality trait of being conscientious who are generally open to new experiences tend to complain more. Interestingly, the authors found that extroverted type does not affect consumer complaining behavior.

Research has also shown that emotions also play a strong part in determining the kind of response. Godwin et al. (1995) and Smith and Ellsworth, (1985) suggest that consumers feel three different types of negative emotions and these negative emotions are materialized in deciding about who to blame for the service failure. People who feel relatively greater anger and disgust are most likely to complain. Complainers and non-complainers were found to be different in that non-complainers were more disconfirmation influenced (Lu-Hsu, Chiu, \& Wei-Ting, 2008). On the contrary, complainers were more likely to have repeat purchases with higher levels of loyalty (Lu-Hsu et al., 2008; Namkung, Jung \& Choi, 2011).

Therefore, it can be proposed that: 
P2a: The social stratum, state and type of consumers' emotions, beliefs and personality will affect the level of consumer dissatisfaction and determine the consumer propensity to complain.

P2b: Consumer patronage or loyalty will affect the level of consumer dissatisfaction and determine the consumer propensity to complain.

\subsubsection{Causal attributions}

Attribution means consumers' beliefs about the firm that it could influence or prevent a failure from occurring (Weiner, 2000; Curren \& Folkes, 1987; Folkes, Koletsky \& Graham, 1987; Hess, Ganesan, \& Klein, 2003; Tsiros et al., 2004; Priluck $\&$ Wisenblit, 2009; Nikbin, Ismail, Marimuthu \& Armesh, 2012). The attributions are internal, external, or a combination of both. Attribution is to explain how an individual might perceive or infer others' dispositions and intentions towards service failure. Consumers who see the cause of the problem as situational where there is no one to blame for tend to feel distressed or fearful and are likely to stay quiet. It has been suggested that if the problem is caused by the consumer himself then he/ she feels shame and guilt and does not complain to the organization (Godwin et al., 1995; Stephens \& Gwinner, 1998; Westbrook, 1987; Nikbin et al., 2015). Therefore, it can be proposed that:

P3: Causal attributions will affect the level of consumer dissatisfaction and determine the consumer propensity to complain.

\subsubsection{Situational and organizational factors}

Consumers' who feel 'small' as compared to the company because of its market strength are not likely to complain. Furthermore, social fear of 'keeping silent' could be one of the emotions consumer feel when they are dissatisfied. This emotion inhibit them to complain as they fear being rude, hurting and bothering others feelings. Also, consumers may feel being compassionate for either an employee and/or the organization (Stephens \& Gwinner, 1998). Since complaining at a certain point may lead to face-to-face communication, so consumers inhibit complaining. Consumers who are dissatisfied are more prone to complaining when the organization is known to be responsive and have a good reputation in consumer complaint handling (Day \& Landon, 1977; Granboi, Summers \& Frazier, 1977).

Hirschman (1970) pointed out the ill effects of a monopolistic nature of competition. He posits that an organization which is enjoying monopoly is at a greater risk of not hearing from its consumers. Tronvol (2007) described the same dilemma by analogizing the situation as 'when exit is closed.' On the other hand, he suggested 
similar consumer complaining phenomena in a competitive environment where consumers quietly switch to other brands and therefore do not necessarily voice their complaints. The time and effort to take up the issue in such an environment is deemed unfruitful and staying or switching to other brands is perceived relatively easier. Therefore, it can be proposed that

P4: Consumer perception of the organizational responsiveness and assurance will affect the level of consumer dissatisfaction and determine the consumer propensity to complain.

\subsubsection{Service failure recovery perceptions}

Consumer service failure recovery mechanisms' success and failures depend on consumer perceptions of the process of complaint and the outcome. Bell and Zemke (1987) propose that apology, urgent reinstatement of the problem, empathy, symbolic atonement and follow-up are the key components of effective service recovery. They posit that apology should be from the front-line service personnel involved who acknowledge that the problem has occurred along with a sincere effort and attitude by taking immediate action to correct the problem. Symbolic atonement is offering services either free of charge or offering substantial discount on the current or future services. Follow-up is approaching the consumer after all the remedial action is carried out in order to find if the service failure has been recovered properly.

Apology is a minimum action that can be taken to offset consumer dissatisfaction when the problem occurs and is recommended as a prerequisite of the service recovery. However, an apology alone is only effective when the magnitude of loss is smaller and becomes ineffective when the service failure or loss is of large value where consumers expect significant tangible compensation (Smith et al., 1998).

In another research, Bitner, Booms and Tetreault (1990) found that forty-three percent of dissatisfied consumers remained dissatisfied due to employee's negative response to a service failure. She explained that consumers are more aggravated when organizations fail to correct the problem even after knowing that the service has failed. According to her, consumers do expect service errors or failures, but dissatisfaction occurs when there is a lack of response from the organization. It is suggested that an organization's response should include four key elements of recovery which includes: acknowledgement of the problem, explanation of the reason for failure, apology where appropriate and compensation such as a free service, replacement and alike. In addition, several studies have shown that the presence of an explanation reduces perceptions of unfairness in certain situations (Baron, 1990).

Kelley et al. (1993) continued on Bitner's (1990) classification in a retail setting by 
identifying subgroups within the three major behavioral classes. These include policy failures, slow or unavailable service, system pricing failure, packaging errors, out of stock, product defects, hold disasters, alterations and repairs, and bad information. A classification of service recovery was also developed that include discount, correction, manager/employee intervention, correction, replacement, apology, and refund. They classified unacceptable service recoveries by consumer-initiated correction (i.e., reactive recovery), store credit, unsatisfactory correction, failure escalation (i.e., double deviation), and no action by service personnel.

Hoffman et al. (1995) offered a failure and recovery typology using Bitner's three major classes with slightly different subgroups in a restaurant setting. Product defects, slow or unavailable service, facility problems, unclear policies, and out-of-stock conditions were common failures in the first behavior class. The third behavioral class included inappropriate employee behaviors, incorrect food orders, lost orders, and mischarged orders. They classified service recovery strategies into free food, food discounts, coupons, management intervention, food replacement, correction of failure, and apology. They identified the service provider's failure to respond as unacceptable to the consumer and leading to extreme dissatisfaction.

Boshoff (1997) confirmed Bell and Zemke's (1990) study results and added that the level of atonement was the most significant main effect and is certainly required when other corrective measures have been executed poorly. The next is the speed of recovery and waiting time where over-delay require considerable levels of atonement to decrease levels of dissatisfaction. A simple apology is of limited impact unless accompanied by some form of compensation. Johnston and Fern (1999) also emphasized on recovery speed and added that cases of 'double deviation' require higher compensation. Roos (1999) studied service failure and recovery and the firm's relationship with the consumer and showed that successful recoveries increase relationship quality i.e., increase consumer trust and commitment towards the organization.

Several authors have employed justice theory in explaining perceived consumer complain behavior. According to Tax, Brown and Chandrashekaran (1998), complaint handling is series of sequential events entailing back and forth communications and interactions ending with the outcome. Accordingly, each part of the sequence is subject to fairness considerations and that each aspect of a complaint resolution creates a justice episode. Within justice theory, justice is divided into three types: distributive, procedural and interactional justice (Walster, Walster \& Berschied, 1978, Tax, Brown, \& Chandrashekaran, 1998; Maxham \& Netemeyer, 2002; Wen \& Chi, 2013; Karatepe \& Vatankhah, 2014; Nikbin et al., 2015). Researchers such as Blodgett, Hill and Tax (1997), and Maxham III and Netmeyer (2003) in their studies found interactional justice significantly more important than the other two. This leads to 
the conclusion that consumers value courtesy and respect the most during complaint handling process, are willing to compromise on other justices and are agreeable to re-patronize the retailer. On the other hand even a full exchange is not enough to overcome the ill will due to being treated rudely. Huang and Lin (2005) add that providing explanation to consumers with a justification result in higher perceived fairness thereby reinforcing the propositions of Greenberg (1994). Tax et al., (1998) posit that the three justices are collectively perceived, complement each other and offset any shortfall of other dimension(s). However, successful service recovery and high level of consumer satisfaction and commitment is achievable when all the three dimensions are addressed in tandem. Collectively, the three dimensions account for over sixty percent of service recovery evaluations (Siu, Zhang, \& Yau, 2013).

P5: Consumer perceived service failure recovery mechanisms will affect the level of consumer dissatisfaction and determine the consumer propensity to complain.

\subsubsection{Past relationship}

The consumer complaining behavior can also depend on their past experiences with the brand/organization. Many researchers in service marketing describe organization-person relationship as identification (Kelley \& Davis, 1994), as an affective commitment (Gruen, Summers \& Acito, 2000), as resistance to counter persuasion and adverse expert opinion (Narayandas, 1998), and as a friendship (Price \& Amould, 1999) which in Oliver's (1997) view, are the antecedents of true loyalty.

Tax et.al (1998) highlighted the role of prior experience with the brand and/or an organization and proved it as a key element in establishing consumer perceptions about the outcome of service recovery. This relates to the Catastrophe model where it is suggested that accumulation of brand equity through satisfying previous experiences will lessen the consumer bad experience of complaint (Oliva, Oliver \& MacMillan, 1992). Accordingly, one poor experience will not affect consumers' commitment and loyalty whose previous experience with the organization is positive (Van-Doorn \& Verhoef, 2008). Therefore, it can be proposed that

P6: Consumer past relationship with the brand/organization will affect the level of consumer dissatisfaction and determine the consumer propensity to complain.

\subsubsection{Switching costs}

Switching costs refers to the perceived monetary and non-monetary costs the consumer incurs in switching towards an alternative (Hirschman, 1970; Burnham \& Mahajan, 2003; Klemperer, 1995). Switching costs can also affect consumers' decision power to stay with the company after a service failure. Higher switching costs are likely 
to pre-empt the consumer to complain and switch towards other brand/organization.

P7: Consumers' switching costs will affect the level of consumer dissatisfaction and determine the consumer propensity to complain and stay/quit the brand/organization.

\section{Methodology}

Owing to the exploratory nature of this study, a qualitative approach was employed to discover the antecedents of consumer complaining behavior that influence the consumer intensity of dissatisfaction and propensity to complain. Since consumer evaluations of services are complex in nature and so are their assessments, therefore interpretive approach is believed to be suited for deeper understanding of the obscure elements of cognitive assessments of service failure and related behavioral responses. Cohen in 1998 suggested that qualitative methods have yielded the most important contributions to the service theory. In this preview, face-to-face interviewing technique is employed. Kvale (1983) described the qualitative research interview as "an interview, whose purpose is to gather descriptions of the life-world of the interviewee with respect to interpretation of the meaning of the described phenomena" (p.174). Face-to-Face interviews are more revealing since the encounter not only offers words and phrases but also provide an opportunity for the interviewer to observe physical cues such as emotions, facial expressions, voice, intonation, body language of the respondent that offers far deeper psychological information and add significant meaning to the respondents' verbatim. There is also an element of synchronous communication of time and place where the servicescape and the standardization of the interaction are taken care of in order to highlight clear and in-depth elements.

A total of thirty (30) interviews are conducted as any new information from the respondents started to diminish which led to the eventual sample size (Glaser \& Strauss, 1967). For phenomenological studies, Creswell (1998) suggests at least twenty five (25) respondents. In addition, the nature of the study demanded purposive sampling technique. The respondents are chosen based on their experience, availability and willingness to effectively communicate their thoughts and ability to understand the purpose and nature of the interview (Bernard, 2002; Patton, 2002; Creswell \& Plano, 2011).

The chosen participants were informed already about the backdrop of the interview so that they were able to recollect relevant negative anecdotes and share them with brevity and relevance. The sample included managers, faculty members, university students and others. The interviews were conducted in the offices and on average each interview took almost 30-45 minutes. The researcher ensured that the interview environment was comfortable in order to allow the respondents to freely 
share and articulate their underlying motivations and perceptions of the situation or issue which is inherently unpleasant and painful to recall (Reppel, Szmigin, \& Gruber, 2006). The respondents were clarified that their responses will remain anonymous for confidentiality and the data will remain secured against any misuse.

The structured interview had eight areas for questions as depicted in the propositions arrived earlier in this research. The first area of questions asked about the intensity of service failure and the magnitude of the dissatisfaction. The second area of questions asked about the type of the service failure and if it affects the level of dissatisfaction and propensity to complain. The third enquired the social and personal factors. The fourth area of questions asked about the role of brand/organizational loyalty. The fifth was about the causal attributions. The sixth inquired about several organizational and personal factors that affect respondent's intensity of dissatisfaction and intention to complain. The seventh category of questions asked about the atonement in terms of perceived organizational justice in response to the complaint. Finally, the eighth area of questions asked about the switching costs attached to the brand/organization. All interviews were transcribed and summarized separately for in-depth analysis.

\section{Findings}

All the interviewee responded that the intensity of service failure did affect their level of dissatisfaction and propensity to complain. When the intensity was high they became more dissatisfied with the service failure and voiced their complaints. None of the respondents quietly switched without complaining when the intensity was high. As one of the interviewees said that:

"In a restaurant, we got the food after one hour of placing the order. We refrained from complaining but were somewhat dissatisfied with the delay. We really didn't want to ruin our mood over a trivial issue and wanted to enjoy. If the delay had persisted, then we would have been very upset and would have complained strongly"

Interestingly, the above statement shows that low intensity does mitigate the dissatisfaction level and propensity to complain respectively however, the propensity to complain is also suppressed by certain personal and/or normative aspects such as fear that voicing complains may negatively affect individual and/or group mood and feelings.

The intensity of service failure and subsequent propensity to complain was also found to be affected by service provider response after the launch of complaint. If the provider response is deemed positive and there is an element of redress, the intensity of failure is likely to deflate. One of the interviewees articulated his incident 
highlighting the above by saying that:

"The failure of my broadband was a terrible experience. My internet was not working properly as there was poor reception of the signals at my place. I was practically out of work. More than half of my work is on the internet. I complained and the delay in fixing the reception issue made me very stressed and frustrated. This was further exacerbated by the concerned call center employee who told me that there must be something wrong with the windows of my computer. This was absurd and totally unacceptable." Hence, P1 is strongly supported.

This respondent also highlights the concept of 'double deviation.' Double deviation in this case refers to the employee inability or unwillingness to respond to service failure situations. In extreme situations, employees may revert the unjustifiable blame on the consumer. This also highlights that the intensity of service failure as perceived by the consumers is indeed a set of series of episodes where each subsequent encounter between the consumer and the service provider determines the level of dissatisfaction and intensity of failure as well as the service recovery outcome. Based on cognitive theories of emotion (Lazarus, Kanner \& Folkman, 1980), double deviation scenarios can be viewed as extremely stressful cognitive appraisals that elicit negative emotions where the 'unjust' response becomes the additional cause of grievance. This snowball effect of repeated errors from the organization's side further aggravates the consumer dissatisfaction level.

In case of emotions, the most visible ones were 'anger,' 'frustration' and 'embarrassment' depicted by the interviewees while recollecting the incidents. In a double deviation scenario, one of the interviewees' narrated the incident by saying that:

"when I went to the body shop for complaining the poor quality of face foundation and when I told the sales girl that she was the one who sold it to me yesterday, the sales girl blatantly refused that she ever sold the face foundation to me. This was so embarrassing."

Besides emotions, type of personality also seems to be affecting the level of dissatisfaction and propensity to complain. All the respondents said that 'aggressive and outspoken' people are likely to be more dissatisfied than others. Another sub-dimension that spawned from the interviews was the 'controlling' personality type which not only reflects the control on the outcome but also on the process. This may be referred to Rotter's (1996) study where he defines such personality factor as a 'locus of control' which measures to what degree a person perceives that rewards are controlled by an individual's actions versus the degree that the person perceives the rewards are controlled by external factors. In this context, one of the interviewees exhibited this 
trait of 'having power over results' because of the external factors, and showed his dissent with the service failure by saying that:

"In my experience, getting poor service comes from not knowing how to get good service. In general, I command good service. Employees know that I know the prices, quality and through my demeanor I exhibit my expectations. If the service fails, then I know I will try to do something to get it fixed the way I want it to be." Therefore, $\mathrm{P} 2 \mathrm{a}$ is supported here.

In addition, the intensity of service failure was found to be strongly related to the 'core' need and want for which the consumer is seeking the service. This means that not all service failure types are equally important and may be ranked ordered. For instance, one of the interviewees explained this phenomenon by saying that:

"Needs are important. If the most important ones are not fulfilled, then I will be very dissatisfied. Teachers' teaching ability is most important that should help us to learn and absorb even the most difficult areas. University administration is the next important aspect followed by physical environment and availability of student services".

Except one interviewee, all respondents believed that social stratum does affect dissatisfaction and propensity to complain. Although these respondents were not very sure that the dissatisfaction across different social stratums would be equal, they were quite sure about the magnitude of the propensity to complain. In this regard, one of the respondents said that:

"Yes, people who believe that they have a high social status are likely to complain more. They will show off their status." Thus, P2a is supported with additional insights.

For causal attributions, all of the respondents said that they will not be dissatisfied and will not complain if the failure occurred due to their own fault. However, they expected redress as a gesture of courtesy from the service provider. However, in case if they believed that the service failure could have been avoided by the service provider, then they would be dissatisfied and probably complain. As one of the respondents said that:

"If the failure occurred because of my own fault, I will not at all be dissatisfied with the service provider. Yes, I want them to replace. For e.g. I broke the glass of water at a famous restaurant chain. If they had not replaced it free of cost, I would have been dissatisfied but would not have complained. If I had thought that they could have avoided the incident, then I would be dissatisfied and complain and if not properly redressed I would probably quit the service provider." P3 is supported with additional insights. 
For service provider's perceived responsiveness, all of the respondents believed that the responsiveness was a key antecedent in encouraging them to voice their complaints. Encouragement was also perceived as a 'hope' for the desired levels of redress and the perceived probability of 'ownership of responsibility' by the service provider. Respondents believed that complaining to such service providers will help them recover from the loss as well as the process itself will be worthwhile. The reciprocal effect of perceived positive responsiveness associations prevailing also revealed a 'soft approach' towards their complaining behavior. In opposite cases, the respondents believed that it was pointless to complain unless the magnitude of the loss is very high. As one of the respondents said that:

"when teachers do not do what they say while grading our papers, it is hurting and I will be disappointed. On the other hand, I will be more dissatisfied with the non-responsive teacher. I will complain to both but will be soft with the responsive teacher and may take the justification easily as compared to the non-responsive teacher." Hence, P4 is supported with additional insights.

Consumers perceptions of complain management system working in organizations was found to be very important precursor of dissatisfaction and propensity to complain. All the respondents were of the opinion that when the complaint management system is perceived positively, dissatisfaction was mitigated, there was a greater propensity to complain and confidence in the recovery process. The type of atonement expected was strongly related to the type and magnitude of the failure. Distributive justice prevailed for failures having a high financial impact. In this case, consumers expected refund, repair, replacement and other justices were perceived irrelevant. For psychosomatic related failures, respondents believed that interactional justice in terms of sincere apology along with procedural ease of voicing the complaint on the higher echelons with prompt feedback was important. In this regard, one of the respondents said that:

"Complain handling perceptions are important. In some of the industries, such as telecom, the complaint management system is very convenient and up to the standard. I may settle down with an apology provided if the loss is trivial. If the loss is financially grave, I would ask for financial compensation as early as possible and would not really care. If there is immense psychological distress then I would be expecting to vent out my grievances and expect a serious or formal apology from a senior person and I may not go there again.” Hence, P5 is supported.

For emotional attachment and patronage/behavioral loyalty point-of-view, respondents have disparate views. Some respondents believed that the relationship with the brand/organization does mitigate their dissatisfaction and their propensity to complain but only for the few and minor service failures. They will be dissatisfied 
and complain if the problem persists. Others said that, they will be very 'hurt' if the service fails and if it is enormous, then would rather quit the brand or service provider in one go. Hence, P6 and P2b are supported here with additional insights.

Finally, the switching costs were found to be strongly associated with dissatisfaction and propensity to complain. All of the respondents said that if the switching costs are high then they would be relatively more dissatisfied and 'frustrated.' On the other hand, if the switching costs are lower, they would like to switch and would not even bother to complain if the intensity of service failure is low. As one of the respondents said that:

"Yes I will be frustrated if the switching costs are high. It is like you are caged in a pigeon hole and cannot find the way out. Complaining will be more intense especially when the service failure is of higher magnitude." So P7 is strongly supported.

\section{Discussion and Future Directions}

The analysis of the interviews uncover key insights regarding consumer responses to service failure. Specifically, the study indicates that there are extenuating factors that affect consumer dissatisfaction and propensity to complain. This also adds to the debate on the sequential responses to the service failures, the obscure role of moderating internal and external factors, and the episodic process of complaint management perceptions by the consumers.

The key finding of this study is that the magnitude of consumer dissatisfaction and propensity to complain is highly dependent on the intensity of service failure. Intensity of service failure can be elaborated in terms of the failure to satisfy the "core need' for which the consumer attains the service. Thus, consumer needs which are apparently in ranked echelons are important predictors of the perceived intensity of failure, magnitude of dissatisfaction and propensity to complain. The lateral needs follow thereafter.

Further, it is also found that the magnitude of the service failure is the direct precursor of dissatisfaction and propensity to complain. Consumers' who perceive that the loss is high, in terms of monetary, interactional and/or procedural owing to the service failure are more dissatisfied and complaining. Importantly, it is clear that the intensity of dissatisfaction is not only dependent on the type and magnitude of the service failure but is in fact directly proportional to the episodic process of seeking the redress where each encounter of the aggrieved consumer with the service provider affects the dissatisfaction level. In other words, the consumer dissatisfaction can be deemed as affected by the longitudinal process of complaint where not only the outcome is important but consumer evaluations of perceived justice along the way 
as well. This finding can be linked to the Tax et al. (1998) study where the authors stated that "Complaint handling can be viewed as a sequence of events in which a procedure, beginning with communicating the complaint, generates a process of interaction through which a decision and outcomes occur. Accordingly, each part of the sequence is subject to fairness considerations and that each aspect of a complaint resolution creates a justice episode" (p. 62).

This finding also links to the concept of 'double deviation' where one service failure is followed by another thereby further aggravating the consumer. Consequently, the intensity of service failures highlights the importance of the need to focus on processes and relationships rather than solely on the outcomes.

Emotions are also important precursors. 'Anger' and 'frustration' are found to be strongly related to the intensity of dissatisfaction and propensity to complain. Especially, aggressive and outspoken people have been found to be deeply expressing dissatisfaction and are more vocal. 'Controlling' personalities that exhibit command over the processes and the outcomes as well are also found to be more dissatisfied and complaining. Interestingly, the dissatisfaction might be the same for people belonging to different social stratum yet high status people are believed to be more vocal. Some consumers may not complain owing to normative influence. However, if the service failure was perceived to be circumstantial or because of personal mistake, the dissatisfaction was there but propensity to complain was low. It was found that consumers do expect recovery from the service provider for trivial losses.

Complaint handling perceptions were found to be important where consumers deemed themselves encouraged to complaining and had optimism that there will be a positive outcome. At the same time, loyalty and patronage were found to be strongly affecting the negative effect of service failure and in mitigating the intensity of dissatisfaction but to an extent. In case of repeated and profound failures, consumers would be dissatisfied and will be prone to complaining. The intensity of dissatisfaction exacerbates when the switching costs are high and consumers may cope with this reality by somehow managing the anxiety and distress and avoid complaining. In wake of the above findings, a modified version of the Hirschman (1970) model is presented here (see Figure 1). It is suggested that the below mentioned model be tested through scientific investigation of quantitative properties to further ratify and generalize the 


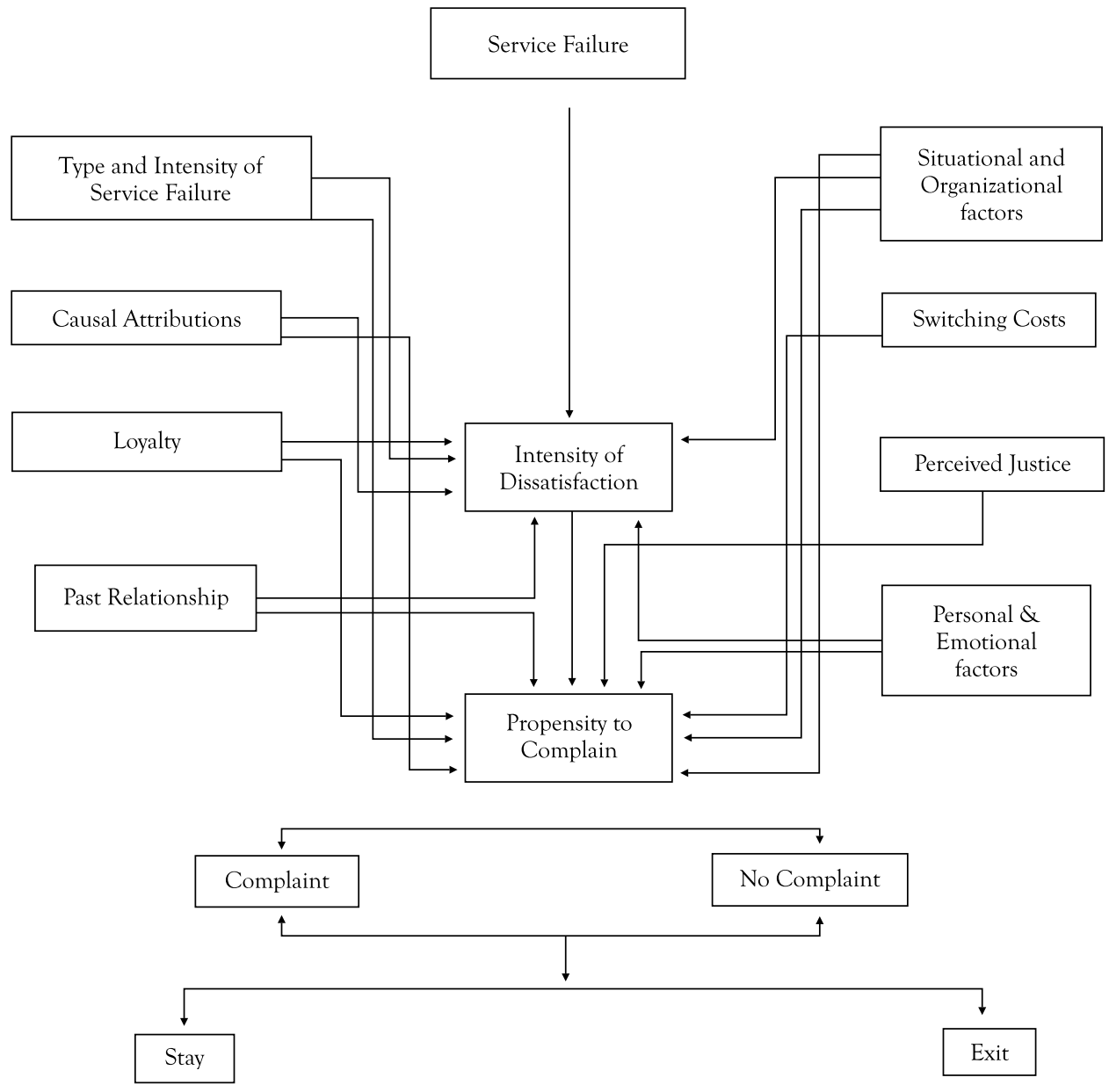

Figure 1: Service Failure, Responses and the intervening Factors: A Holistic Diagrammatical Template

above findings thereby presenting a more robust and generalizable model for both the academicians and practitioners of service businesses.

\section{References}

Al-Refaie, A., Bata, N., Eteiwi, D., Jalham, I. (2014). Examining factors that affect passenger's overall satisfaction and loyalty: Evidence from Jordan airport. Jordan Journal of Mechanical and Industrial Engineering, 8(2): 94-101.

Baron, R. A. (1990). Countering the effects of destructive criticism: The relative efficacy of four interventions. Journal of Applied Psychology, 75, 235-245.

Bearden, W.O., \& Mason, J. B. (1984). An investigation of influences on consumer complaint reports. 
Advances in Consumer Research, 11, 490-495.

Bejou, D., \& Palmer, A. (1998). Service failure and loyalty: An exploratory empirical study of airline consumers. Journal of Services Marketing, 12 (1), 7-22.

Bell, C. R., \& Zemke, R. (1987). Service breakdown: the road to recovery. Management Review, 76(10), $32-35$.

Bernard, H. R. (2002). Research methods in anthropology: Qualitative and quantitative approaches ( $3^{\text {rd }}$ ed.). Alta Mira Press; Walnut Creek, CA.

Berry, L. L. (1980). Services marketing is different. Business, 30, 24-29.

Berry, R., Tanford, S., Montgomery, R., \& Green, A. (2014). How we complain the effect of personality on consumer complaint channels. Journal of Hospitality $\mathcal{E}$ Tourism Research. 42(1), 74-101.

Bitner, M. J., Booms, B. H., \& Tetreault, M. S. (1990). The service encounter: Diagnosing favorable and unfavorable incidents. Journal of Marketing, 54(January), 71-84.

Bitner, M. J., Brown, S. W., \& Meuter, M. L. (2000). Technology infusion in service encounters. Journal of Academy of Marketing Science, 28(1), 138-149.

Blodgett, J. G., Hill, D. J. \& Tax, S. S. (1997). The effects of distributive, procedural, and interactional justice on post complaint behavior, Journal of Retailing, 2, 185-210.

Boshoff, C. (1997). An experimental study of service recovery options. International Journal of Service Industry Management, 88(2), 110-130.

Chang, L., \& Huang, S. (2013). Adoption and loyalty toward low cost carriers: The case of Taipei-Singapore passengers. Transportation Research: Part E: Logistics and Transportation Review, 50, 29-36.

Chang, Y. W., \& Chang, Y. H. (2010). Does service recovery affect satisfaction and consumer loyalty? An empirical study of airline services. Journal of Air Transport Management, 16(6), 340-342.

Choi, S. \& Mattila, A., S. (2008). Perceived controllability and service expectations: influences on consumer reactions following service failure. Journal of Business Research, 61(1), 24-30.

Creswell, J. W. (1998). Qualitative inquiry and research design: Choosing among five traditions. Thousand Oaks, CA: Sage Publications.

Creswell, J. W. \& Plano, C. V. L. (2011). Designing and conducting mixed method research (2 ${ }^{\text {nd }}$ ed.). Los Angeles: Sage Publications.

Cropanzano, R. (1998). Organizational justice and culture. Paper presented at the 13th annual conference of the society for industrial and organizational Psychology, Dallas TX.

Curren, M. T., \& Folkes, V. S. (1987). Attributional influences on consumers' desires to communicate about products. Psychology $\mathcal{E}$ Marketing, 4, 31-45. 
Day, R. L. (1984). Modeling choices among alternative responses to dissatisfaction. Advances in Consumer Research, 11, 496-499.

Day, R. L., \& Ash, S. B. (1979). Consumer response to dissatisfaction with durable products. Advances in Consumer Research, 6, 438-444.

Day, R. L., \& Landon, Jr., E. L. (1976). Toward a theory of consumer complaining behavior. In A. Woodside, J. Sheth \& P. Bennett (Eds.), Consumer and industrial buying behavior. (pp. 425-437). Amsterdam: North Holland Publishing Company.

Ding, M. C., Ho, C. W., \& Lii, Y. S. (2015). Is corporate reputation a double-edged sword? Relative effects of perceived justice in airline service recovery. International Journal of Economics and Business Research, 10(1), 1-17.

Dube L., \& Maute, M. (1996). The antecedents of brand switching, brand loyalty \& verbal responses to service failures. In T. Swartz, D. Bowen \& S. Brown, (Eds.), Advances in services marketing and management (127-151). Amsterdam: Elsevier BV.

Ekinci, Y., Calderon, J. \& Siala, H. (2016). Do personality traits predict 'complaining' consumers? Journal of Business Environment, 8(1), 32.

Fisk, R. P., Brown, S. W., \& Bitner, M. J. (1993). Tracking the evolution of the services marketing literature. Journal of Retailing, 69(1), 61-103.

Folkes, V. S., Koletsky, S., \& Graham, J. L. (1987). A field study of causal inferences and consumer reaction: The view from the airport. Journal of Consumer Research, 13, 534-539.

Folkes, V. S. (1988). Recent attribution research in consumer behavior: A review and new directions. Journal of Consumer Research, 14(4), 548-565.

Fornell, C., \& Westbrook, R. (1979). An exploratory study of assertiveness, aggressiveness, and consumer complaining behavior. Advances in Consumer Research, 6, 105-110.

Garín-Muñoz, T., Pérez-Amaral, T., Gijón, C., \& López, R. (2016). Consumer complaint behavior in telecommunications: The case of mobile phone users in Spain. Telecommunications Policy, 40, 804-820.

Gelbrich, K. \& Roschk, H. (2011). A meta-analysis of organizational complaint handling and consumer responses. Journal of Service Research, 14(1). 24-43.

Glaser, B. G. \& Strauss, A. L. (1967). The discovery of grounded theory: Strategies for qualitative research. Piscataway, New Jersey: Transaction.

Godwin, B., Patterson, P. G. \& Johnson, L. W. (1995). Emotion, coping and complaining propensity following a dissatisfactory service encounter. Journal of Consumer Satisfaction, Dissatisfaction and Complaining Behavior, 8, 155-163.

Granbois, D., Summers, J.O., \& Frazier, G.L. (1977). Correlates of consumer expectations and complaining behavior, Consumer Satisfaction, Dissatisfaction and Complaining Behavior, 8, 18- 25. 
Greenberg, J. (1994). The quest for justice on the job: Essays and experiments. Thousand Oaks, Calif: Sage Publications.

Harris, K. E., Grewal, D., Mohr, L. A., \& Bernhardt, K. L. (2006). Consumer responses to service recovery strategies: The moderating role of online versus offline environment. Journal of Business Research, 59(4), 425-431.

Hart, C. W. L., Heskett, J. L. \& Sasser, W. E. (1990). The profitable art of service recovery. Harvard Business Review, (July-August), 149-156.

Hart, C. W. L. (1988). The power of unconditional service guarantees. Harvard Business Review, 66 (July-August), 54-62.

Hess, R. L. (2008). The impact of firm reputation and failure severity on consumers' responses to service failures. Journal of Services Marketing, 22(5), 385-398.

Hess, R. L., Ganesan, S., \& Klein, N. M. (2003). Service failure and recovery: The impact of relationship factors on consumer satisfaction. Journal of the Academy of Marketing Science, 31(2), 127-145

Hirschman, A. O. (1970). Exit, voice and loyalty: Responses to decline in firms, organizations and states. Cambridge: Harvard University Press.

Hoffman, K. D., Kelley, S. W. \& Rotalsky, H. M. (1995). Tracking service failures and employee recovery efforts. Journal of Services Marketing, 9(2), 49-61.

Hofstede (1991). Cultures and organizations: Software of the mind. London: McGraw Hill.

Hui, M. K., \& Au, K. (2001). Justice perceptions of complaint-handling: A cross-cultural comparison between PRC and Canadian consumers. Journal of Business Research, 52, 161-173.

Huang, J., \& Lin, C. (2008). Effect of advance explanations on customer-perceived justice, satisfaction and loyalty improvement. Social Behavior and Personality: An International Journal, 36, 65-66..

Huang, M. C., F., Tsang, A., \& Zhou, N. (2011). Making your online voice loud: The critical role of WOM information. European Journal of Marketing. 45(7/8), 1-21,

Johnston, R. \& Fern, A. (1999). Service recovery strategies for single and double deviation scenarios. The Service Industries Journal, 19(2), 69-82.

Keaveney, S. M. (1995). Consumer switching behavior in service industries: An exploratory study. Journal of Marketing, 59(April), 71-82.

Kelley, S. W., K. Hoffman, D., \& Davis, M.A. (1993). A typology of retail failures and recoveries. Journal of Retailing, 69(4), 429-452.

Kim, M. G., Wang, C., \& Mattila, A. S. (2010). The relationship between consumer complaining behavior and service recovery: An integrative review. International Journal of Contemporary Hospitality Management, 22(7), 975-991. 
Kitapci, O., \& Dortyol, I. T. (2009). The differences in consumer complaint behavior between loyal consumers and first comers in the retail banking industry: The case of Turkish consumers. Management Research News, 32(10), 932-941.

Kraft, F. B. (1977). Characteristics of consumer complainers and complaint repatronage behavior. In R. L. Day \& H. K. Hunt (Eds.), Consumer satisfaction, dissatisfaction and complaining behavior proceedings. (pp. 79-84). Bloomington: Indiana University.

Karatepe, O. M., \& Ekiz, E. H. (2004). The effects of organizational responses to complaints on satisfaction and loyalty: A study of hotel guests in Northern Cyprus. Managing Service Quality, 14(2), 476-486.

Karatepe, O. M., \& Vatankhah, S. (2015). High-performance work practices, career satisfaction, and service recovery performance: A study of flight attendants. Tourism Review,70(1), 56-71

Landon, E. L. (1976). A model of consumer complaint behavior. Consumer Satisfaction, Dissatisfaction and Complaining Behavior, 8(4)31-35.

Lee, E. J., \& Park, J. K. (2010). Service failures in online double deviation scenarios justice theory approach. Managing Service Quality, 20(1), 46-69.

Liu, R. R., \& McClure, P. (2001). Recognizing cross-cultural differences in consumer complaint behavior and intentions: An empirical examination. Journal of Consumer Marketing, 18(1), 54-74.

Lu-Hsu, J., Chiu, V., \& Wei-Ting (2008). Complaints and perceptions management: Perceptions and perspectives of online credibility. Journal of Enterprise Information Management, 23(5), 653-660

McQuilken, L., \& Robertson, N. (2011). The influence of guarantees, active requests to voice and failure severity on consumer complaint behavior. International Journal of Hospitality Management, 30, 953-962

Malhotra, N. K., Oly-Ndubisi, N., \& Agarwal, J. (2008). Public versus private complaint behavior and consumer defection in Malaysia, appraising the role of moderating factors. Esic Market, (September-December), 27-59.

Matilla, A. S. (1999). The role of culture in the service evaluation processes. Journal of Service Research, 1, 250-61.

Maxham III, J. G., \& Netmeyer, R. G. (2003). Firms reap what they sow: The effects of shared values and perceived organizational justice on consumers evaluations of complaint handling. Journal of Marketing, 67(1), 46-62.

Miller, J. L., Craighead, C. W., \& Karwan, K. R. (2000). Service recovery: A framework and empirical investigation. Journal of Operations Management, 18(4), 387-400.

Moyer, M. S. (1984). Characteristics of consumer complainants: implications for marketing and public policy. Journal of Public Policy and Marketing, 3, 67-84.

Namkung, Y., Jang, S. C. \& Choi, S. K. (2011). Consumer complaints in restaurants: Do they differ by service stages and loyalty levels? International Journal of Hospitality Management. 30, 495-502. 
Nikbin, D., Ismail, I., Marimuthu, M., \& Armesh, H. (2012). Perceived justice in service recovery and switching intention: Evidence from Malaysian mobile telecommunication industry. Management Research Review, 35(3/4), 309-325.

Nikbin, D., Hyun, S. S., Baharun, R., \& Tabavar, A. A. (2015). The determinants of consumers' behavioral intentions after service failure: The role of emotions. Asia Pacific Journal of Tourism Research, 20(9), 971-989.

Ng, S., David, M. E., \& Dagger, T. S. (2011). Generating positive word-of-mouth in the service experience. Managing Service Quality: An International Journal, 21(2), 133-151.

Oliva, T. A., Oliver, R. L. \& MacMillan, I. C. (1992). A catastrophe model for developing service satisfaction strategies. Journal of Marketing, 56(3), 83-95.

Ors, H., Yilmaz, V. Sen, R. (2015). A structural equation model for the description and omparison of complaint behavior after purchasing of electronic, food and textile products. Journal of Business, Economics $\mathcal{E}$ Finance, 4(2), 268-288

Patton, M. Q. (2002). Qualitative research and evaluation methods ( $3^{\text {rd }}$ ed.). Sage Publications: Thousand Oaks, CA.

Priluck, R., \& Wisenblit, J. (2009). Consumers' responses to service debacles and subsequent recovery. Services Marketing Quarterly, 30, 365-376.

Reichheld, F. F. (1993). Loyalty-based management. Harvard Business Review, 71(2), 64-73.

Reichheld, F. F., \& Sasser, W. E. Jr. (1990). Zero defections: Quality comes to services. Harvard Business Review, 68(5), 105-112

Richins, M. L. (1983). Negative word-of-mouth by dissatisfied consumers: A pilot study. Journal of Marketing, 47(1), 68-78.

Roos, I. (1999). Switching processes in consumer relationships. Journal of Service Research, 2(1), 68-85.

Schoefer, K., \& Ennew, C. T. (2003). Consumer evaluations of tour operators responses to their complaints: An exploratory study. Journal of Travel and Tourism Marketing, 15(2), 83-92.

Singh, J. (1988). Consumer complaint intentions and behavior: Definitional and taxonomical Issues. Journal of Marketing, 52(1), 93-107.

Singh, J. (1990). Voice, exit, and negative word-of-mouth behaviors: An investigation across three service categories. Journal of the Academy of Marketing Science, 18(1), 1-15.

Siu, N. Y. M., Zhang, T. J. F., \& Yau, C. Y. J. (2013). The roles of justice and consumer satisfaction in consumer retention: A lesson from service recovery. Journal of Business Ethics, 114, 675 - 686.

Smith, A. K., \& Bolton, R. N. (1998). An experimental investigation of consumer reactions to service failure and recovery encounters. Journal of Service Research, 1(1), 65-81. 
Smith, C. A., \& Ellsworth, P. C. (1985). Patterns of cognitive appraisal in emotion. Journal of Personality and Social Psychology, 48(4), 813-818.

Sparks, B. A., \& McColl-Kennedy, J. R. (2001). Justice strategy options for increased consumer satisfaction in a services recovery setting. Journal of Business Research, 54(3), 209-218.

Stephens, N., \& Gwinner, K. P. (1998). Why don't some people complain: A cognitive-emotive process model of consumer complaint behavior. Journal of the Academy of Marketing Science, 26(3), 172-189.

Swanson, S., \& Hsu, M. (2011). The effect of recovery locus attributions and service failure severity on word-of-mouth and repurchase behaviors in the hospitality industry. Journal of Hospitality $\mathbb{E}$ Tourism Research, 35(4), 511-529.

Tax, S. S., \& Brown, S. W. (1998). Recovering and learning from service failure. Sloan Management Review, 40(1), 75-88.

Tax, S. S., Brown, S. W., \& Chandrashekaran, M. (1998). Consumer evaluations of service complaint experiences. Journal of Marketing, 62(1), 60-76.

Technical Assistance Research Programs (1979). Consumer complaint handling in America: Summary of findings and recommendations. US Office of Consumer Affairs, Washington, DC.

Technical Assistance Research Program (1986). Consumer complaint handling in America: An update study. Washington: White House Office of Consumer Affairs.

Technical Assistance Research Program (1999). Basic facts on consumer complaint behavior and the impact of service on the bottom line. Competitive Advantage, June, 1-4.

Tronvoll, B. (2007). Consumer complaint behavior from the perspective of the service-dominant logic of marketing. Managing Service Quality, 17, 601- 620.

Tsiros, M., Mittal, V., \& Ross, W. T. (2004). The role of attributions in consumer satisfaction: A reexamination. Journal of Consumer Research, 31(2), 476-483.

Walster, E., Walster, G. W., \& Berscheid, E. (1978). Equity: Theory and research. Boston: Allyn and Bacon.

Warland, R. H., Robert, O. H., \& Dan E. M. (1984). Consumer complaining and community involvement: An exploration of their theoretical and empirical linkages. Journal of Consumer Affairs, 18(3), 64-78.

Warland, R. H., Robert, O. H., \& Jane, W. (1975). Dissatisfied consumers: Who gets upset and what do they do about it? Journal of Consumer Affairs, 9(2), 152-162.

Wen, B., \& Chi, C. G. (2013). Examine the cognitive and affective antecedents to service recovery satisfaction: A field study of delayed airline passengers. International Journal of Contemporary Hospitality Management, 25(3), 306-327.

Westbrook, R. A. (1987). Product/consumption-based affective responses and post purchase processes. 
Journal of Marketing Research, 24(3), 258-270.

Wiggins, J. S. (1996). The five-factor model of personality: Theoretical perspectives. New York: Guilford.

Zaltman, G., Srivastava, R. K., \& Deshpande, R. (1978). Perceptions of unfair marketing practices: Consumerism implications. ACR North American Advances.

Zemke R., \& Bell, C. (1990). Service recovery: doing it right the second time. Training, 27(2), 42-48. 
